\title{
UPAYA PENINGKATAN KETERAMPILAN BERBICARA DALAM PEMBELAJARAN TEMATIK TERPADU MELALUI PI-MTPS KELAS IV SD
}

\author{
Dian Indah Suryani ${ }^{1}$, Naniek Sulistya Wardani ${ }^{2}$, Tego Prasetyo ${ }^{3}$ \\ 1,2,3 Program Studi Pendidikan Guru Sekolah Dasar, Universitas Kristen Satya Wacana, \\ Salatiga, Indonesia \\ e-mail : $292014061 @$ student.uksw.edu,wardani.naniek@gmail.com dan \\ prasetyotego@gmail.com
}

\begin{abstract}
ABSTRAK
Penelitian Tujuan penelitian ini adalah untuk mengetahui apakah peningkatan keterampilan berbicara tematik terpadu dapat diupayakan melalui pendekatan inkuiri dan model TPS kelas IV SD semester 2 tahun pelajaran 2017/2018. Jenis penelitian ini adalah penelitian tindakan kelas (PTK), dengan menggunakan model spiral dari C. Kemmis dan Robin Mc. Taggart. Prosedur penelitian menggunakan 2 siklus, masingmasing siklus terdiri dari 3 tahap yakni, 1) perencanaan tindakan 2) pelaksanaan tindakan dan observasi, 3) refleksi. Subyek penelitian adalah siswa kelas IV SDN Tembarak Temanggung dengan 27 siswa yang terdiri dari 14 siswa laki-laki dan 13 siswa perempuan. Teknik pengumpulan data menggunakan observasi yang dilengkapi dengan rubrik pengukuran. Teknik analisis data adalah teknik persentase yakni membandingkan keterampilan berbicara dalam pembelajaran tematik terpadu melalui PI-MTPS antar siklus. Hasil penelitian menunjukkan bahwa terdapat peningkatan keterampilan berbicara tematik terpadu, yang diupayakan melalui PI-MTPS antar siklus, yakni sebanyak $44,4 \%$ dari seluruh siswa mencapai keterampilan berbicara tinggi di siklus 1 dan meningkat menjadi $81,4 \%$ dari seluruh siswa di siklus 2 . Keterampilan berbicara dalam pembelajaran tematik terpadu meliputi keterampilan membuat rumusan masalah, keterampilan mengemukakan pendapat, terampil membaca puisi dengan intonasi, pelafalan dan ekpresi yang tepat serta lancar membaca puisi.
\end{abstract}

.Kata Kunci: keterampilan berbicara, pendekatan inkuiri dan model TPS (PI-MTPS)

\begin{abstract}
The purpose of this study is to determine whether the improvement of integrated thematic speaking skills can be pursued through inquiry approach and model of TPS class IV SD 2nd semester of the academic year 2017/2018. This type of research is a classroom action research (PTK), using a spiral model of C. Kemmis and Robin Mc. Taggart. The research procedure uses 2 cycles, each cycle consists of 3 stages namely, 1) action planning 2) implementation of action and observation, 3) reflection. The subjects of the study were fourth grade students of SDN Tembarak Temanggung with 27 students consisting of 14 male students and 13 female students. Technique of collecting data using observation equipped with rubric measurement. Data analysis technique is a percentage technique that compares speaking skill in integrated thematic learning through PI-MTPS between cycles. The results showed that there was an increase in integrated thematic speaking skills, which were attempted through PI-MTPS between cycles, ie as many as $44.4 \%$ of all students achieved high speaking skills in cycle 1 and increased to $81.4 \%$ of all students in cycle 2 . Speech skills in integrated thematic learning include skill in making problem formulation, opinion expression skills, skillful reading of poetry with accurate intonation, pronunciation and expression and fluent poetry reading.
\end{abstract}

Keywords: speaking skills, inquiry approach and TPS model (PI-MTPS). 


\section{PENDAHULUAN}

Suasana belajar di sekolah didesain agar peserta didik dapat aktif mengembangkan potensi diri yang meliputi spiritual keagamaan, pengendalian diri, kepribadian, kecerdasan, akhlak mulia, serta keterampilan yang diperlukan untuk dirinya, masyarakat, bangsa dan negara. (UU Sisdiknas No 20 tahun 2003; ps 1.1). Proses pembelajaran pada satuan pendidikan yang dilakukan guru diupayakan interaktif antar siswa, interaktif antara guru dan siswa, pembelajaran yang inspiratif, menyenangkan, materi yang menantang, aktivitas pembelajarannya memotivasi peserta didik untuk berpartisipasi aktif, serta memberikan ruang yang cukup. Proses pembelajaran yang diselenggarakan secara interaktif membutuhkan komunikasi yang baik. Salah satu keterampilan komunikasi adalah keterampilan berbicara, yang merupakan salah satu kompetensi siswa yang harus dicapai dalam pembelajaran tematik muatan bahasa Indonesia.

Berbicara adalah salah satu bentuk tindakan yang mempunyai peran penting untuk menyampaikan pesan. Berbicara yang baik dan benar akan menghasilkan pesan yang diharapkan dan sesuai dengan pemberi pesan. Keterampilan berbicara dilatihkan pada peserta didik melalui proses pembelajaran. Keterampilan berbicara merupakan keterampilan yang tidak mudah dilakukan oleh peserta didik. Oleh karena itu, agar terampil berbicara, peserta didik membutuhkan latihan yang intensif dalam mengelola gagasan dan pendapat yang dimiliki untuk dapat menyampaikan pesan dengan baik.

Kondisi pembelajaran peserta didik kelas 4 SDN Tembarak Temanggung pada semester 1 tahun pelajaran 2017/2018, pembelajaran berpusat pada guru. Kesempatan peserta didik untuk mengemukakan pendapat secara lesan dengan berbicara sangat terbatas. Waktu sepenuhnya dimanfaatkan oleh guru untuk menjelaskan materi pembelajaran. Peserta didik kurang terlatih untuk berbicara di dalam kelas.

Dalam pembelajaran tematik di kelas, peserta didik jarang diminta untuk membuat rumusan masalah, peserta didik menjadi tidak aktif untuk belajar, dan kurang berani untuk mengemukakan pendapat secara lisan. Untuk mengurangi masalah dalam pembelajaran, guru dapat mendesain model pembelajaran yang inovatif. Salah satu model pembelajaran yang dapat digunakan untuk meningkatkan keterampilan berbicara, adalah pendekatan pembelajaran inkuiri dan model think pair share (PI-MTPS). Dalam pembelajaran PI-MTPS peserta didik terdorong untuk berani berbicara menyampaikan pendapatnya.

Permasalahan pembelajaran yang ada di sekolah adalah permasalahan keterampilan berbicara peserta didik perlu ditingkatkan, melalui pembelajaran yang inovatif. Permasalahan pembelajaran merupakan permasalahan yang urgen dan mendesak, sehingga perlu segera diatasi. Untuk itu, penelitian yang bertujuan untuk mengetahui apakah pembelajaran PI-MTPS dapat meningkatkan keterampilan berbicara tematik peserta didik kelas IV SD, segera dilakukan.

Keterampilan berbicara merupakan suatu keterampilan yang digunakan untuk melakukan komunikasi secara lisan. Keterampilan menyampaikan informasi dalam berkomunikasi sering disertai dengan ekspresi. Kasbiyono (2012) menjelaskan bahwa keterampilan berbicara merupakan salah satu dari empat keterampilan berbahasa (menyimak, berbicara, membaca, dan menulis). Keterampilan berbicara mempunyai peranan yang penting karena melalui berbicara yang baik akan mempermudah penyampaian pesan kepada orang lain. Keterampilan berbicara yang kurang lancar akan mengganggu kelangsungan proses komunikasi antara pemberi pesan dan penerima pesan.

Keterampilan berbicara menyangkut aspek kebahasaan dan aspek non kebahasaan. Menurut Arsyad dan Mukti (1993), aspek kebahasaan meliputi ketepatan ucapan, penempatan tekanan, pilihan kata, dan ketepatan sasaran pembicaraan, sedangkan aspek non kebahasaan meliputi sikap yang tenang, pandangan harus diarahkan pada lawan bicara, gerak-gerik dan mimik yang tepat, kenyaringan suara, kelancaran, relevansi/ penalaran, dan penguasaan topik. Aspek kebahasaan yang dijelaskan Arsyad dan Mukti, juga dijelaskan oleh Azizah \& 
Kurniawati (2013:53), yang menjelaskan bahwa aspek kebahasaan dalam keterampilan berbicara meliputi aspek pengucapan, aspek pembentukan kalimat dan aspek pengembangan kosakata. Aspek non-kebahasaan meliputi aspek keberanian, aspek kelancaran dan aspek ekspresi. Jadi keterampilan berbicara adalah keterampilan yang dimiliki oleh seseorang untuk mengkomunikasikan pesan secara alami kepada orang lain, melalui latihan berbicara yang terdiri dari aspek kebahasaan (ketepatan ucapan, penempatan tekanan, pilihan kata, ketepatan sasaran pembicaraan, pengembangan kosa kata, dan pembentukan kalimat) dan aspek non kebahasaan (keberanian, kelancaran, dan sikap yang tenang).

Keterampilan berbicara dapat ditingkatkan melalui skenario pembelajaran. Penelitian tentang keterampilan berbicara dengan mendesain pembelajaran telah dilakukan oleh Hanifah Yuniarti (2013) yang menemukan bahwa, penerapan Model TPS dengan video pembelajaran dapat meningkatkan keterampilan berbicara siswa Kelas III SD, dari siklus 1 sebesar 2,4 meningkat menjadi 2,6 di siklus 2, dan meningkat menjadi 2,72 di siklus 3 . Keterampilan berbicara meliputi pemilihan kata, pelafalan kalimat, sikap siswa dan keberanian, ketepatan isi yang dibicarakan, dan kelancaran saat berbicara.

Drake (2012) mendefinisikan thematic approach is one of the teaching strategy that uses themes toward creating active, interesting, and meaningful learning. Dalam pembelajaran pendekatan tematik diharapkan dapat menciptakan pembelajaran yang bermakna, yang dapat mendorong peserta didik untuk menemukan pengetahuan dari apa yang di pelajari kemudian pengetahuan yang diperoleh dikaitkan dengan pengetahuan yang sudah ada. Pelaksanaan pembelajaran yang bermakna dapat menggunakan PI-MTPS.

Hidayat, Festiyed, \& Fauzi (2012:5) menjelaskan bahwa pendekatan pembelajaran inkuiri menekankan peserta didik untuk mencari dan menemukan sendiri jawaban dari suatu masalah yang dipertanyakan. Selanjutnya Wardani Naniek S. (2016:81), menjelaskan bahwa MTPS adalah model pembelajaran yang melibatkan siswa untuk berfikir, berdiskusi dengan pasangannya dan hasil dari diskusi kemudian di sharing-kan pada teman-teman di kelas. Dengan demikian, pembelajaran PIMTPS adalah pembelajaran yang menekankan peserta didik untuk mencari dan menemukan sendiri jawaban dari masalah yang dipertanyakan dengan cara, peserta didik berfikir sendiri, berdiskusi dengan pasangannya dan berbagi kepada teman di kelas.

Langkah-langkah pembelajaran dengan PI menurut Winanto \& Makahube (2016:19), Halim, \& Khaldun, (2014:56), Kawuri (2017:907) terdiri dari 1) menjelaskan tujuan pembelajaran, 2) merumuskan masalah, 3) merumuskan hipotesis, 4) mengumpulkan data, 5) menganalisis data, 6) menguji hipotesis, 7) merumuskan kesimpulan dan 8) mempresentasikan. Langkah-langkah yang digunakan untuk melaksanakan MTPS adalah 1) siswa menyimak tujuan pembelajaran dan kompetensi yang ingin dicapai, 2) siswa diminta untuk berfikir tentang permasalahan yang diberi (think), 3) siswa diminta berdiskusi berpasangan (pairing) dengan teman sebelahnya dan mengutarakan hasil pemikiran masingmasing, 4) siswa mengikuti diskusi, secara pleno dan sharing, 5) siswa menyimak penjelasan guru, 6) siswa membuat kesimpulan (Wardani Naniek S., 2016:81).

Pembelajaran PI-MTPS digunakan untuk meningkatkan keterampilan berbicara. Besarnya keterampilan berbicara diukur melalui keberanian merumuskan masalah, mengekspresikan pendapat dalam diskusi, sharing skema siklus hidup hewan dengan lancar dan sharing slogan upaya pelestarian dengan lancar, dan penyampaian puisi pelestarian siklus hidup hewan berdasarkan lafal, intonasi dan ekspresi. PI-MTPS adalah pembelajaran yang menekankan peserta didik untuk mencari dan menemukan sendiri jawaban dari masalah tema 6 Cita-Citaku, subtema 2 Hebatnya Cita-Citaku dan Berusaha Meraih Cita-Cita dilakukan dengan cara; 1) menyimak materi belajar siklus hidup hewan dan upaya pelestariannya, 2) berfikir merumuskan masalah siklus hidup hewan dan upaya pelestariannya, 3) berdiskusi merumuskan masalah siklus hidup hewan dan upaya pelestariannya dengan pasangannya, 4) 
merumuskan hipotesis siklus hidup hewan dan upaya pelestariannya, 5) membuat skema siklus hidup hewan, 6) sharing pembuktian hipotesis siklus hidup hewan dan upaya pelestariannya dalam diskusi pleno, dan 7) melisankan puisi. Penjelasan kerangka berfikir secara rinci, disajikan melalui gambar 1di halaman berikut.

\section{METODE PENELITIAN}

PTK ini dilaksanakan pada peserta didik kelas IV SDN Tembarak Temanggung semester 2 tahun pelajaran 2017/2018. Subyek penelitian adalah peserta didik kelas IV SD, yang berjumlah 27 peserta didik, dan terdiri dari 14 peserta didik laki-laki dan 13 peserta didik perempuan.

Dalam penelitian ini terdapat dua variabel yaitu keterampilan berbicara dan PI-MTPS. Keterampilan berbicara adalah keterampilan yang diukur melalui keberanian merumuskan masalah, mengekspresikan pendapat dalam diskusi, sharing skema siklus hidup hewan dengan lancar dan sharing slogan upaya pelestarian dengan lancar, dan penyampaian puisi pelestarian siklus hidup hewan berdasarkan lafal, intonasi dan ekspresi.

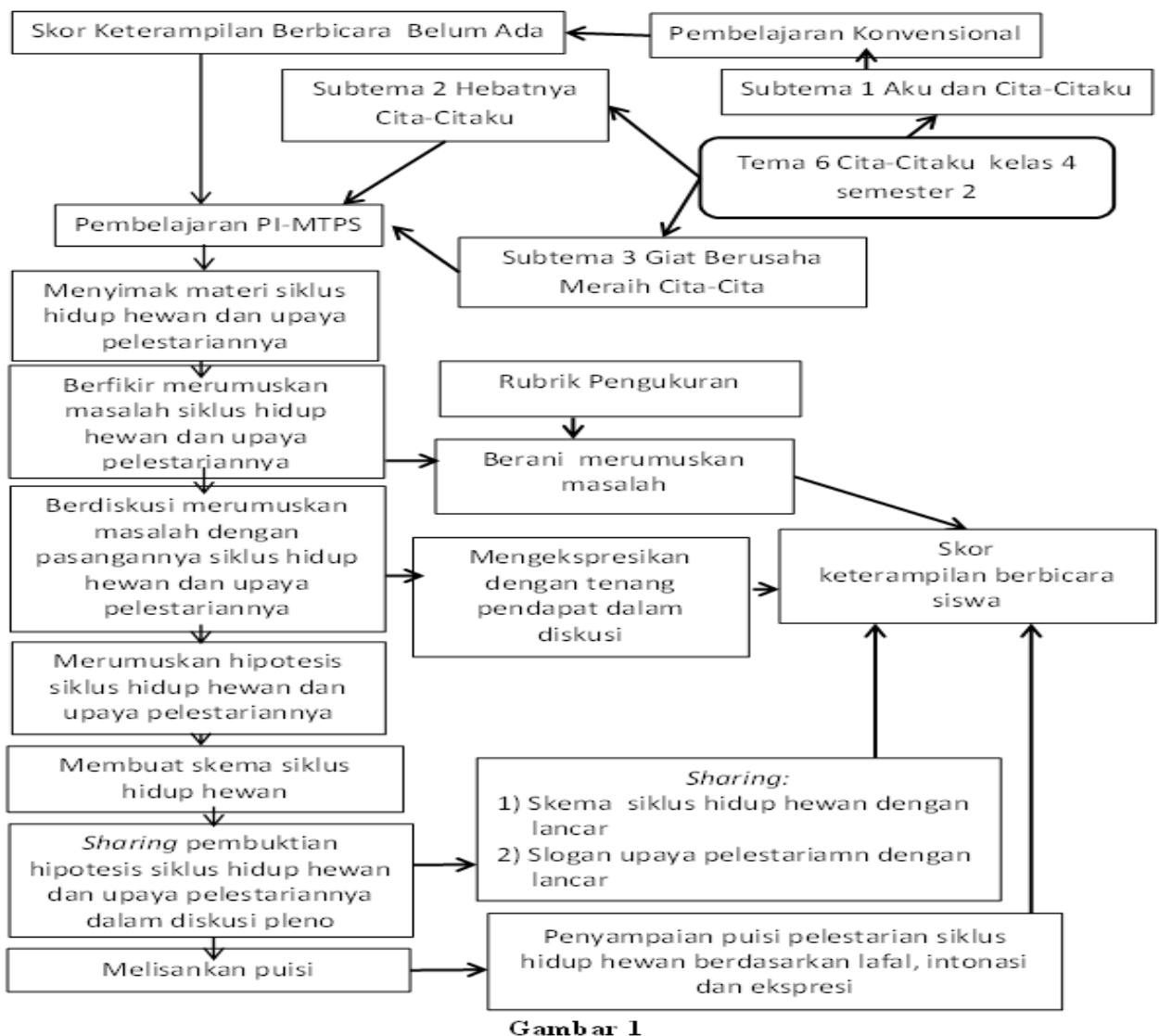

Skema Upaya Peningkatan Keterampilan Berbicara Tema 6 Cita-Citaku Subtema 2 Heb atnya Cita-Citaku Melalui PI-MTPS

PI-MTPS adalah pembelajaran yang menekankan peserta didik untuk mencari dan menemukan sendiri jawaban dari masalah tema 6 Cita-Citaku, subtema 2 Hebatnya Cita-Citaku dan Berusaha Meraih Cita-Cita yang dilakukan dengan cara; 1) menyimak materi belajar siklus hidup hewan dan upaya pelestariannya, 2) berfikir merumuskan masalah siklus hidup hewan dan upaya pelestariannya, 3) berdiskusi merumuskan masalah siklus hidup hewan dan upaya pelestariannya dengan pasangannya, 4) merumuskan hipotesis siklus hidup hewan dan upaya pelestariannya, 5) membuat skema siklus hidup hewan, 6) sharing pembuktian hipotesis siklus hidup hewan dan upaya pelestariannya dalam diskusi pleno, dan 7) melisankan puisi. 
Jenis penelitian ini adalah penelitian tindakan kelas (PTK) dengan prosedur PTK menggunakan minimal dua siklus. Setiap siklus terdiri dari tiga tahap yakni, tahap perencanaan, implementasi tindakan dan observasi, refleksi. Model PTK menggunakan model spiral yang dikemukakan oleh Stephen Kemmis dan Robin Mc.Taggart. Tahapan kegiatan pada setiap siklus secara rinci dijelaskan melalui gambar 2 berikut ini.

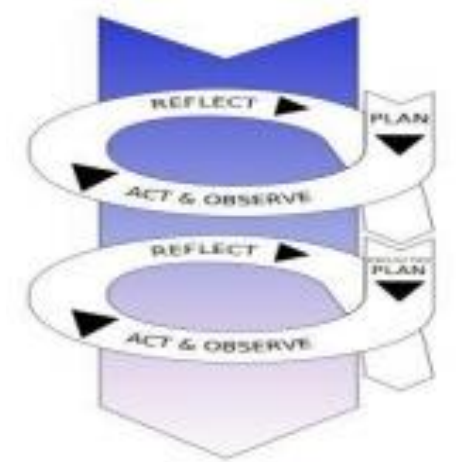

Gambar 2

PTK Model Spiral dari Stephen Kemmis dan Robin Mc.Taggart

Teknik pengumpulan data yang digunakan dalam penelitian ini adalah teknik non tes dengan instrumen unjuk kerja yang dilengkapi rubrik pengukuran keterampilan berbicara. Penelitian ini dikatakan berhasil, jika jumlah siswa yang terampil berbicara mencapai $\geq 80 \%$ dari seluruh siswa, dan mencapai skor $\geq 70$.

Teknik analisis data adalah teknik statistik komparatif yaitu teknik statistik yang membandingkan persentase keterampilan berbicara siswa siklus 1 dan siklus 2.

\section{HASIL DAN PEMBAHASAN}

Peningkatan keterampilan berbicara bagi peserta didik kelas IV SD diupayakan dengan memberi tindakan yang berupa strategi pembelajaran yakni PI-MTPS. Pembelajaran PI-MTPS dilakukan melalui prosedur siklus. Pembelajaran PI-MTPS merupakan pembelajaran yang berpusat pada siswa (student center). Pelaksanaan pembelajaran tematik terpadu melalui PIMTPS dengan 7 (tujuh) langkah.

Prosedur siklus 1 terdiri dari 3 tahap. Tahap 1 adalah tahap perencanaan tindakan.
Dalam tahap perencanaan tindakan siklus 1, kegiatan yang dilakukan adalah penyusunan perangkat pembelajaran berupa penyusunan RPP beserta perangkatnya. Penyusunan RPP menggunakan tema 6 Cita-Citaku dan subtema 2 Hebatnya Cita-Citaku di desain dengan PI-MTPS. Pemetaan matapelajaran adalah IPA dan Bahasa Indonesia. Pemetaan Kompetensi Dasar (KD) adalah KD 4.2 Membuat skema siklus hidup beberapa jenis makhluk hidup yang ada di lingkungan sekitarnya, dan slogan upaya pelestariannya, dan KD 4.6 Melisankan puisi hasil karya pribadi dengan lafal, intonasi, dan ekspresi yang tepat sebagai bentuk ungkapan diri. Di samping itu, membuat materi siklus hidup hewan dan upaya pelestarian, membuat media pembelajaran berupa gambar siklus hidup hewan, membuat kisi-kisi keterampilan berbicara, menyusun lembar observasi implementasi RPP, dan menyusun rubrik penilaian keterampilan berbicara.

Tahap ke 2 adalah tahap implementasi tindakan dan observasi. Dalam kegiatan ini, guru melaksanakan pembelajaran sesuai dengan RPP yang telah disiapkan. Dalam pelaksanaan pembelajaran, dilakukan observasi oleh teman sejawat untuk mengecek apakah pelaksanaan pembelajaran sesuai dengan RPP yang telah dirancang. Dalam pelaksanaan observasi disediakan lembar observasi untuk guru dan siswa.

Kegiatan belajar terdiri dari kegiatan pendahuluan, kegiatan inti dan kegiatan penutup. Kegiatan pendahuluan berisi warming up dan penjelasan tujuan pembelajaran. Kegiatan inti berisi langkahlangkah pembelajaran PI-MTPS dan kegiatan penutup menekankan pada membuat kesimpulan dan pesan moral.

Tahap ke 3 adalah tahap refleksi. Tahap refleksi dilakukan setelah pelaksanaan pembelajaran. Kelemahan dari pelaksanaan tindakan PI-MTPS di siklus 1 adalah kekurang kesiapan guru dalam mengimplementasikan RPP, sehingga langkah kegiatan pendahuluan, guru tidak memperhatikan pengaturan tempat duduk peserta didik, tidak memperhatikan waktu yang sudah dialokasikan untuk pembelajaran PI-MTPS, guru belum sepenuhnya sebagai fasilitator yang baik 
dan kurang melibatkan peserta didik dalam membuat kesimpulan di akhir pembelajaran, peserta didik belum berani mengemukakan rumusan masalah kepada guru dan masih ada yang bermain sewaktu peserta didik lain sedang membacakan puisi didepan kelas. Di samping itu, kesungguhan peserta didik dalam mengikuti kegiatan pembelajaran belum maksimal, dan keaktifan peserta didik dalam mengikuti kegiatan pembelajaran kurang. Dengan demikian, masih perlu membiasakan peserta didik untuk aktif belajar dan belajar bersama.

Kelebihan PI-MTPS, siswa terdorong lebih aktif belajar dalam menyimak materi, guru terpaksa harus belajar mendesain pembelajaran dan berlatih mengimplementasikan RPP dengan benar.
Dalam pembelajaran PI-MTPS capaian yang akan diperoleh adalah meningkatnya keterampilan berbicara peserta didik. Keterampilan berbicara peserta didik dalam pembelajaran tematik diukur melalui instrumen lembar observasi yang dilengkapi dengan rubrik unjuk kerja. Pengukuran keterampilan berbicara siswa terdiri dari 5 indikator, yaitu keberanian merumuskan masalah, mengekspresikan pendapat dalam diskusi, sharing skema siklus hidup hewan, sharing slogan upaya pelestarian, dan penyampaian puisi pelestarian siklus hidup hewan berdasarkan lafal, intonasi dan ekspresi.

Keterampilan berbicara siswa kelas IV SD dalam pembelajaran tematik terpadu melalui PI-MTPS, secara rinci disajikan melalui Tabel 1.

Tabel 1. Distribusi Frekuensi Keterampilan Berbicara Dalam Pembelajaran Tematik Terpadu Melalui PI-MTPS Siklus 1

\begin{tabular}{|c|c|c|c|c|c|c|c|c|c|c|c|c|c|c|}
\hline \multirow{2}{*}{$\begin{array}{c}\text { Indikator } \\
\begin{array}{c}\text { Klasifikasi Keterampian } \\
\text { Berbicara }\end{array}\end{array}$} & \multicolumn{2}{|c|}{1} & \multicolumn{2}{|r|}{2} & \multicolumn{2}{|c|}{3} & \multicolumn{2}{|c|}{4} & \multicolumn{2}{|c|}{5} & \multicolumn{2}{|c|}{6} & \multicolumn{2}{|c|}{7} \\
\hline & Fre & $\%$ & Fre & $\%$ & Fre & $\%$ & Fre & $\%$ & Fre & $\%$ & Fre & $\%$ & Fre & $\%$ \\
\hline Tinggi & 18 & 66,7 & 24 & 88,9 & 20 & 74,1 & 18 & 66,7 & 16 & 59,3 & 16 & 59,3 & 23 & 85,2 \\
\hline Sedang & 8 & 29,6 & 3 & 11,1 & 7 & 25,9 & 9 & 33,3 & 9 & 33,3 & 9 & 33,3 & 4 & 14,8 \\
\hline Rendah & 1 & 3,7 & 0 & 0 & 0 & 0 & 0 & 0 & 2 & 7,4 & 2 & 7,4 & 0 & 0 \\
\hline Jumlah & 27 & 100 & 27 & 100 & 27 & 100 & 27 & 100 & 27 & 100 & 27 & 100 & 27 & 100 \\
\hline
\end{tabular}

Sumber: Data Primer

Keterangan : 1 = Keberanian merumuskan masalah; 2 = Mengekspresikan pendapat dalam diskusi; 3 = sharing skema siklus hidup hewan; 4=sharing slogan upaya pelestarian; 5=penyampaian puisi pelestarian siklus hidup hewan berdasarkan lafal; $6=$ penyampaian puisi pelestarian siklus hidup hewan berdasarkan intonasi; $7=$ penyampaian puisi pelestarian siklus hidup hewan berdasarkan ekspresi. Fre=Frekuensi; \%=Persentase

Tabel 1 menunjukkan keterampilan berbicara peserta didik tinggi (skor 75-100) yang mencapai di atas $75 \%$ adalah mengekspresikan pendapat dalam diskusi dan penyampaian puisi pelestarian siklus hidup hewan berdasarkan ekspresi. Keterampilan berbicara peserta didik sedang (skor 50-74) terbanyak dicapai peserta didik adalah sharing slogan upaya pelestarian; penyampaian puisi pelestarian siklus hidup hewan berdasarkan lafal; dan penyampaian puisi pelestarian siklus hidup hewan berdasarkan intonasi masing-masing 33,3\% dari seluruh peserta didik. Keterampilan berbicara peserta didik rendah (skor 25-49) yang dicapai oleh peserta didik terbanyak pada kegiatan penyampaian puisi pelestarian siklus hidup hewan berdasarkan lafal; dan penyampaian puisi pelestarian siklus hidup hewan berdasarkan intonasi.

Hasil keterampilan belajar tematik siswa masih belum mencapai maksimal 100 $\%$. Oleh karena itu, siklus 2 perlu segera dilaksanakan. Prosedur siklus 2, digunakan untuk memantapkan pendekatan dan model pembelajaran yang digunakan dan tercapainya keterampilan berbicara tinggi. Pelaksanaan siklus 2 sesuai dengan siklus 1 .

Keterampilan berbicara siswa kelas IV SD dalam pembelajaran tematik terpadu melalui PI-MTPS pada siklus 2. Kelemahan dari pelaksanaan tindakan PI-MTPS di siklus 2 adalah guru sudah siap 
mengimplementasikan RPP dengan baik, namun waktu yang digunakan kelebihan sedikit. Pengaturan tempat duduk peserta didik sudah lebih baik, meski belum tertata secara optimal, masih perlu meningkatkan kebiasaan peserta didik untuk aktif belajar dan belajar bersama. Kelebihan PI-MTPS, siswa lebih aktif belajar dalam menyimak materi, guru semakin berlatih mengimplementasikan RPP dengan benar. Adapun keterampilan berbicara peserta didik di siklus 2, secara rinci disajikan melalui tabel 2.

Tabel 2. Distribusi Frekuensi Keterampilan Berbicara Dalam Pembelajaran Tematik Terpadu Melalui PI-MTPS Siklus 2

\begin{tabular}{ccccccccccccccccc}
\hline Indikator & \multicolumn{1}{c}{} & $\mathbf{1}$ & $\mathbf{2}$ & $\mathbf{3}$ & $\mathbf{4}$ & $\mathbf{5}$ & \multicolumn{6}{c}{$\mathbf{6}$} & \multicolumn{7}{c}{$\mathbf{7}$} \\
\hline $\begin{array}{c}\text { Klasifikasi Ketrampil } \\
\text { Berbicara }\end{array}$ & Fre & $\%$ & Fre & $\%$ & Fre & $\%$ & Fre & $\%$ & Fre & $\%$ & Fre & $\%$ & Fre & $\%$ \\
Tinggi & 24 & 85,2 & 26 & 96,3 & 26 & 96,3 & 25 & 92,6 & 27 & 100 & 27 & 100 & 27 & 100 \\
Sedang & 4 & 14,8 & 1 & 3,7 & 1 & 3,7 & 2 & 7,4 & 0 & 0 & 0 & 0 & 0 & 0 \\
Jumlah & 27 & 100 & 27 & 100 & 27 & 100 & 27 & 100 & 27 & 100 & 27 & 100 & 27 & 100 \\
\hline
\end{tabular}

Sumber: Data Primer

Keterangan : 1 = Keberanian merumuskan masalah; 2 = Mengekspresikan pendapat dalam diskusi; 3 = sharing skema siklus hidup hewan; 4 = sharing slogan upaya pelestarian; 5 = penyampaian puisi pelestarian siklus hidup hewan berdasarkan lafal; $6=$ penyampaian puisi pelestarian siklus hidup hewan berdasarkan intonasi; $7=$ penyampaian puisi pelestarian siklus hidup hewan berdasarkan ekspresi. Fre $=$ Frekuensi; \%=Persentase

Dari Tabel 2 menunjukkan keterampilan berbicara peserta didik tinggi (skor 75-100) yang mencapai lebih dari 75 $\%$ dari seluruh peserta adalah seluruh indikator, dan bahwa indikator 5, 6 dan 7 yaitu penyampaian puisi pelestarian siklus

hidup hewan berdasarkan lafal; intonasi dan ekspresi mencapai $100 \%$. Keterampilan berbicara peserta didik sedang (skor 50-74) terbanyak dicapai peserta didik adalah keberanian merumuskan masalah sebesar $14,8 \%$ dari seluruh peserta didik. Keterampilan berbicara peserta didik rendah (skor 25-49) pada siklus 2 tidak ada yang mencapainya atau $0 \%$.

Keterampilan berbicara pada siklus 1 dan siklus 2, menunjukkan adanya peningkatan, yang secara rinci dapat dilihat pada Tabel 3.

Tabel 3. Distribusi Frekuensi Keterampilan Berbicara Dalam Pembelajaran Tematik Terpadu Melalui PI-MTPS Siklus 1 dan Siklus 2

\begin{tabular}{cccccc}
\hline \multirow{2}{*}{ Rentang skor } & \multicolumn{2}{c}{ Kriteria Keterampilan } & \multicolumn{2}{c}{ Siklus 1 } & \multicolumn{2}{c}{ Siklus 2 } \\
& Berbicara & Fre & \% & Fre & \% \\
\hline $75-100$ & Tinggi & 12 & 44,4 & 22 & 81,4 \\
$50-74$ & Sedang & 11 & 40,7 & 5 & 18,5 \\
$25-49$ & Rendah & 4 & 14,8 & 0 & 0 \\
& Jumlah & 27 & 100,00 & 27 & 100,00 \\
\hline
\end{tabular}

Sumber: Data primer

Tabel 3 menunjukkan capaian keterampilan berbicara dalam pembelajaran tematik terpadu pada siklus 1 sebesar 12 peserta didik $(44,4 \%$ dari 27 peserta didik), dan siklus 2 sebesar 22 peserta didik $(81,4 \%$ dari 27 peserta didik). Nampak terdapat kenaikan jumlah peserta didik yang mencapai keterampilan berbicara tinggi dari siklus 1 ke siklus 2 yaitu dari 12 peserta didik (44,4\% dari 27 peserta didik), menjadi 22 peserta didik $(81,4 \%$ dari 27 peserta didik). Desain pembelajaran tematik terpadu melalui PI-MTPS terbukti dapat meningkatkan keterampilan berbicara siswa kelas IV SD Negeri pada siklus 1 ke siklus 2. Peningkatan keterampilan berbicara 
karena siswa membuat rumusan masalah, mengemukakan pendapat, membaca puisi dengan intonasi, pelafalan dan ekpresi yang tepat serta lancar, berarti siswa terlibat langsung dalam pembelajaran. Keterlibatan siswa dalam pembelajaran ini seperti yang dikemukakan oleh Hidayat, Festiyed, \& Fauzi (2012:5) dan Wardani N. S. (2016:81), yang menjelaskan bahwa pembelajaran PIMTPS merupakan pembelajaran yang melibatkan siswa secara langsung. Pembelajaran yang dilaksanakan, yang dapat meningkatkan keterampilan berbicara, menggunakan langkah-langkah 1) menyimak materi siklus hidup hewan dan upaya pelestariannya, 2) berfikir merumuskan masalah siklus hidup hewan dan upaya pelestariannya, 3) berdiskusi merumuskan masalah siklus hidup hewan dan upaya pelestariannya dengan pasangannya, 4) merumuskan hipotesis siklus hidup hewan dan upaya pelestariannya, 5) membuat skema siklus hidup hewan, 6) sharing pembuktian hipotesis siklus hidup hewan dan upaya pelestariannya dalam diskusi pleno, dan 7) melisankan puisi. Langkah-langkah pembelajaran ini, juga dilakukan oleh Winanto \& Makahube (2016:19), Halim, \& Khaldun, (2014:56), Kawuri (2017:907) dan Wardani Naniek S. (2016:81).

Peningkatan keterampilan berbicara siswa dapat di klasifikasikan menjadi tiga, yaitu keterampilan berbicara tinggi, sedang, dan rendah. Peningkatan keterampilan berbicara tematik terpadu, nampak pada banyaknya capaian keterampilan berbicara tinggi siklus 1 sebanyak 44,4\% dari seluruh siswa dan meningkat menjadi $81,4 \%$ dari seluruh siswa di siklus 2. Keterampilan berbicara dalam pembelajaran tematik terpadu meliputi keterampilan membuat rumusan masalah, keterampilan mengemukakan pendapat, terampil membaca puisi dengan intonasi, pelafalan dan ekpresi yang tepat serta lancar membaca puisi.

Keterampilan berbicara dapat ditingkatkan melalui skenario pembelajaran PI-MTPS. Peningkatan keterampilan berbicara ini, juga didukung oleh hasil penelitian yang dilakukan oleh Denna Akhmad Yulian (2015). Temuan yang diperoleh menyatakan bahwa peningkatan keterampilan berbicara melalui model model pembelajaran TPS, meningkatkanketerampilan berbicara dari siklus 1 keterampilan berbicara berkategori kurang, meningkat di siklus 2 keterampilan berbicara berkategori baik dan meningkat lagi di siklus 3 menjadi keterampilan berbicara berkategori sangat baik. Begitu pula PTK yang dilakukan oleh Hesti Kartikasari pada tahun 2014, menunjukkan terdapat peningkatan keterampilan berbicara tinggi dari siklus 1 sebanyak 13 siswa (52\%) dari seluruh siswa menjadi 22 siswa (88\%) dari seluruh siswa di siklus 2 .

Hipotesis penelitian yang menyatakan bahwa peningkatan keterampilan berbicara tema 6 CitaCitaku subtema 2 Hebatnya Cita-Citaku dan subtema 3 Giat Berusaha Meraih Cita-Cita diduga dapat diupayakan melalui PI-MTPS siswa kelas IV SDN Tembarak Temanggung semester 2 tahun pelajaran 2017/2018 terbukti, yang ditunjukkan oleh keterampilan berbicara tinggi dari siklus 1 ke siklus 2 yaitu dari 12 peserta didik $(44,4 \%$ dari 27 peserta didik), menjadi 22 peserta didik (81,4\% dari 27 peserta didik) melalui PI-MTPS.

\section{SIMPULAN DAN SARAN}

Simpulan penelitian ini adalah terdapat peningkatan keterampilan berbicara tematik terpadu melalui PIMTPS. Peningkatan keterampilan berbicara ditunjukkan oleh besanya persentase peserta didik yang mencapai keterampilan berbicara tinggi di siklus 1 sebesar $44,4 \%$ dari seluruh peserta didik yang ada, meningkat menjadi 81,4\% dari seluruh peserta didik yang ada di siklus 2. Keterampilan berbicara peserta didik dalam pembelajaran tematik terpadu meliputi keterampilan membuat rumusan masalah, keterampilan mengemukakan pendapat, keterampilan 
membaca puisi dengan intonasi, pelafalan dan ekpresi yang tepat serta lancar membaca puisi.

Saran diberikan untuk Guru kelas IV, agar mencoba mendesain pembelajaran PI-MTPS, dan kepada Kepala sekolah agar memotivasi guru untuk melakukan inovasi pembelajaran terutama untuk meningkatkan keterampilan berbicara peserta didik.

\section{DAFTAR RUJUKAN}

Arsyad, Maidar dan Mukti U.S. (1993). Pembinaan Kemampuan Berbicara Bahasa Indonesia. Jakarta: Erlangga.

Azizah, N., \& Kurniawati, Y. (2013). Tingkat Keterampilan Berbicara Ditinjau Dari Metode Bermain Peran Pada Anak Usia 5-6 Tahun. Indonesian Journal of Early Childhood Education Studies 2 (1), 53.

Drake, S. M. (2012). Creating standards based integrated curriculum: the commom core state standards edition. California: Corwin Press A sage Publication.

Hidayat, S., Festiyed , \& Fauzi, A. (2012). Pengaruh Pemberian Assessment Essay Terhadap Pencapaian Kompetensi Siswa Dalam Pembelajaran Fisika Menggunakan Pendekatan Ekspositori dan Inkuiri di Kelas XII A SMA N 1 Kecamatan Suliki Kabupaten Lima Puluh Kota. Jurnal Penelitian Pembelajaran Fisika ISSN: 2252-3014, 3, 5.

Kasbiyono. (2012). Peningkatan Keterampilan Berbicara Pada KD Bermain Peran Dengan Menggunakan Media Karim Bagi Siswa Kelas VIII C SMP Negeri 2 Gajah Demak Tahun Pelajaran 2008/2009. Jurnal MPP Vol 6, No 1.

Kawuri, A. S. (2017). Upaya Peningkatan Hasil Belajar IPS Melalui Pendekatan Inkuiri dan Model Pembelajaran
Student Team Achievement Division (STAD) Siswa Kelas IV SD. Jurnal Mitra Pendidikan (JMP Online), 907.

Kemendikbud. (2016). Permendikbud Nomor 22 Tahun 2016 Tentang Standar Proses Pendidikan dan Menengah. Jakarta: Kemendikbud.

Nurhadisah, Halim, A., \& Khaldun, I. (2014). Pembelajaran Kooperatif Tipe Numbered Head Together dengan Pendekatan Inkuiri untuk Meningkatkan Penguasaan Konsep Kalor Siswa SMA. Jurnal Pendidikan Sains Indonesia, Vol. 02, No.01, hlm 54-64, 56.

Saputri, D. F., Fadilahb, S., \& Wahyu. (2016). Efektivitas Penggunaan Buku Ajar Fisika Matematika Berbasis Inkuiri dalam Perkuliahan Fisika Matematik. Jurnal Penelitian \& Pengembangan Pendidikan Fisika Volume 2 Nomor 2, 8.

Shofa, M. F., \& Suparno. (2014). Peningkatan Keterampilan Berbicara Anak Usia Dini Melalui Permainan Sandiwara Boneka. 210: Jurnal Pendidikan dan Pemberdayaan Masyarakat, Volume 1 - Nomor 2, November 2014.

Trianto. (2013). Mendesain Model Pembelajaran Inovatif-Progresif. Jakarta: Kencana Prenada Media Group.

Wardani, Naniek Sulistya (2016). Implementasi Teknik Penilaian Autentik Perkuliahan Kajian IPS SD Tipe Think Pair share (TPS). Jurnal ISPI Jawa Tengah, volume 3 nomor 1 ISSN 2442-6350, 8.

Winanto, A., \& Makahube, D. (2016). Implementasi Strategi Pembelajaran Inkuiri Untuk Meningkatkan Motivasi dan Hasil Belajar IPA Siswa Kelas 5 SD Negeri Kutowinangun 11 Kota Salatiga. Scholaria, Vol. 6 No. 2, 119.

Yulian, D. A. (2015). Peningkatan Keterampilan Berbicara Siswa 
Melalui Penerapan Model Kooperatif Tipe Think Pair And Share Dalam Pembelajaran IPS. Ejournal upi, 910.

Yuniarti, H. (2013). Penerapan Model Think

Pair Share Dengan Video Pembelajaran Untuk Meningkatkan Keterampilan Berbicarasiswa Kelas III SDN Karanganyar 02 Semarang. Upaya Peningkatan Keterampilan Berbicara, Hal. 90-176. 